Article

\title{
Water load-shedding in Beaufort West, South Africa: Lessons learnt and applied during the 2009-2011 and 2017-2019 droughts
}

\author{
Wessel P. Visser ${ }^{1}$
}

\author{
1 Department of History, Stellenbosch University, Stellenbosch 7602, South Africa \\ * Correspondence: wpv@sun.ac.za
}

\begin{abstract}
Increasing and prolonged droughts have become a feature of the South African environmental landscape. This article investigates the sustainability of water procurement to the rural town of Beaufort West and the reasons for the town's water provision crises during the droughts of 2009-2011 and 2017-2019. Innovative solutions were reached to alleviate the serious water-shortages during these droughts. Data to illustrate population increases and precipitation decreases, which impacted on the town's water resources, was collected from census records of Statistics South Africa and from the Department of Water and Sanitation, respectively. A number of risk factors contributed to the town's water crises, e.g. unsustainable water extraction at times of serious droughts, poor water monitoring, metering and attention to leakages, an expansion of informal settlements within the municipal boundaries of Beaufort West, as well as annual rainfall patterns that became increasingly unpredictable. The article concludes that water resource development had not kept pace with demand, therefore water infrastructure should be built with enough capacity to cope with regular dry periods. Equilibrium should be reached between the water expectations of the community and water availability to avoid future social instability in waterstressed towns such as Beaufort West.
\end{abstract}

Keywords: Beaufort West, drought, Gamka Dam, boreholes, water loadshedding, reclamation plant, municipality, bottled water

\section{Introduction}

Increasing and prolonged drought conditions have prompted urgent research on the sustainability of water procurement and provision to rural communities in the arid interior of South Africa. In turn the research stimulated much relevant literature. As early as 2009 a study by Le Maitre et al. [1] focused on the challenge to provide adequate water resources in the water-scarce region of the Little Karoo. Holloway et al. [2] published a report on the acute water shortages during the 2009-2011 drought in the Central Karoo. Meissner and Jacobs-Mata [3] probed the South African water sector's long-term national drought policy and strategy to improve the country's response to future droughts. Schreiner et al. [4] investigated the economic impacts of drought and water shortages on agricultural, livestock, tourism, mining, and business during the period 2011-2016, while research by Tfwala et al. [5] determined the occurrence and severity of droughts and interannual 
rainfall variability trends in the Ghaap plateau, Northern Cape Province, South Africa. Zhang et al. [6] presented a conceptual framework within which numerical modelling of aquifer systems is operated to improve water security. And Visser [7] investigated the chronology of Cape Town's 2015-2018 drought and the various measures imposed by the city council to preserve dwindling water supplies to try and avert the socalled Day Zero scenario when its water resources would run out.

The studies mentioned above focused on the problems experienced by predominantly agricultural communities under the strain of serious droughts and efforts to provide water security in arid regions such as the Karoo, the Northern Cape, the West Coast and even Cape Town as a city with limited freshwater resources. However, there is a lacuna in the literature on water studies that focus on the responses and dynamics of rural town communities with a history of coping with water provision struggles during times of severe drought duress. This article investigates the reasons for the water provision crises of the town of Beaufort West in the Central Karoo region during the droughts of 2009-2011 and 2017-2019 and the innovative solutions reached to alleviate the problems of water scarcity.

\section{Research Methods}

The study is based on a comprehensive research into the history and processes of water provision to water-stressed rural towns in South Africa. For the Beaufort West case study municipal council minutes, reports and documents were scrutinized in the Western Cape Archives and Records Service (WCARS) in Cape Town. This research material was complemented with data from various published scientific articles and reports, press releases and media reports pertaining to Beaufort West's water woes.

For the graph indicating population growth (see Figure 1) data was collected from the official census records, dating from 1921 to 2011 via Statistics South Africa (Stats SA). To collect data for Beaufort West, census years were used when there was a count of the full population [8]. The graphs in Figures 2 and 3 were compiled using data collected from the Department of Water and Sanitation (DWS). In Figure 2 the annual total rainfall for each year from 1993-2020 was calculated, adding them and dividing the total by the number of years for which data was provided. In Figure 3 the DWS data was compiled to and run through a Standard Precipitation Index (SPI), "which for any location is based on the longterm precipitation record for a desired period" [9]. The SPI was used to calculate the average rainfall in comparison to the previous 12 months over a 40 year period. The SPI generally notes years from 0 to -1 as being low rainfall years, -1 to -2 as being severe drought years and from -2 to 3 as an extreme drought [10].

\section{West}

\section{Geographical, demographic and climatological features of Beaufort}

Beaufort West was "proclaimed a town in 1818 and was the first town in South Africa to receive municipal status as early as 1837". The town is situated in the semi-arid central Great Karoo, $491 \mathrm{~km}$ from Cape Town and $961 \mathrm{~km}$ from Johannesburg and is "the major administrative, agricultural and economic centre of the region. The town also serves as a major road, and rail transit and crossing to other towns in South Africa. Beaufort West lies in a hollow between two hills and is flanked by the 
Gamka River in the west and the Kuils River in the east. Both rivers, which became semi-perennial as a result of urbanization, flow in a generally north to south direction". With an average annual rainfall of a mere $165 \mathrm{~mm}$ the municipality has two main sources of water: borehole water and surface runoff that is captured in two dams. The Springfontein Dam, an irrigation reservoir, was completed in 1869 but has run dry for several years because of diminishing precipitation. The Gamka Dam, completed in 1955, which provides $45 \%$ of the town's water supply, is the town's major freshwater reservoir but has been experiencing severe water-stressed conditions in recent years. Therefore, the town's water supply is heavily reliant on rainfall.

Groundwater, extracted from boreholes, "played an increasingly important role in the development of Beaufort West. The town is known for its so-called 'dyke', a useful barrier against the southward migration of underground water because it effectively compartmentalizes the groundwater flow. The 'dyke' is an inclined sheet or sill of dolerite which dips into the north at an approximate $17^{\circ}$ angle. The sheet outcrops in an approximately east-west direction. A certain amount of water penetrates to depth to the north of the sheet as is localized in the northern part of Beaufort West in what might be regarded as an underground reservoir and where the relatively impenetrable dolerite sheet forces the water towards the surface. South of the dolerite sheet, the underground water supply is not sufficient to be extracted. Consequently, most springs are situated towards the northern parts of town and in periods of drought this was the area where the municipal council was prone to drill new boreholes in search of more water resources" [11-14].

\subsection{Underlying factors towards the droughts of the 2021 century}

Throughout its municipal history Beaufort West was plagued by occational floods and recurring periods of prolonged drought. Visser [15] and Vivier and Vivier [11] determined that during the first 143 years of municipal record keeping serious droughts appeared in 1823, 1827, 18561859, 1876-1878, 1898, 1915-1916, 1926, 1942-1949, 1951 and 1955-1966. In fact, Beaufort West's first water shedding appeared in January 1946, amidst the 1942-1949 drought, when the situation became so critical that water provision to inhabitants was cut on certain days and hours. And in October 1949 water rationing was imposed so that the daily water supply was restricted to two hours only [16].

As explained above, groundwater supplies would become crucial in periods when the town suffered from inevitable drought and water duress. Between 150 and 200 boreholes were drilled north of the dolerite sheet by the late 1940s in search of water [15] and according to Erasmus [12] 18 were sunk since 1985 with an average depth of 49.83 metre. Xu et al. [14] established that "the importance of groundwater has increased from $50 \%$ in 1978 to $55 \%$ in 2007 ".

A major game changer in Beaufort West's water woes was the introduction of a water-borne sewerage system. Although such a sewerage scheme was considered as early as 1963 by the municipal council the project eventually started in 1975 and was completed in 1978. "The installation of flush toilets and running water to poor neighbourhoods has increased water demand and the successful service 
provision had the unintended consequence of promoting futher inmigration of inhabitants from under-served areas" $[2,12,17]$. Secondly, sustained urban growth between 1921 and the early 2000s had implications for municipal water demand in Beaufort West (see Figure 1). This growth was also "being accompanied by significant town expansion from 1945 to 2010" [2]. According to Nel et al. [18] "the growth of larger towns in the Karoo can be attributed to their jobs, touristic and retirement appeal. Such towns are servicing an enlarged hinterland and a larger resident population while also providing services to an external market driven by tourism and leisure in a 'postproduction' era".

Field research by Holloway et al. [2] suggested that "heavy rain patterns had shifted spatially in recent years". According to information gathered from local monitors "rainfall changes had taken place since the 1980s as rain began to fall predominantly over the town itself and not over the Gamka Dam mountain catchment as before. This had implications both for surface water supply, as well as access to groundwater, due to slower rates of aquifer recharge". These findings concur with the data in Figures 2 and 3. Figure 2 indicates a declining trend in rainfall figures since the early 2000s and the SPI findings (see Figure 3) clearly show the severe drop in precipitation during the 20092011 and 2017-2019 droughts.

According to Mishra and Singh [9] the droughts that hit Beaufort West and its surrounding district in 2009-2011 and 2017-2017 can be described in four categories:

1. "A meteorological drought which is defined as a lack of precipitation over a region for a period of time.

2. A hydrological drought which is related to a period with inadequate surface and subsurface water resources (lakes, reserviors, rivers, streams and ground water) for established water uses of a given water resources management system. It affects non-agricultural activities such as urban water consumption, ecosystem preservation, tourism and recreation.

3. An agricultural drought which refers to a period with declining soil moisture and consequent crop failure.

4. A socio-economic drought which is associted with failure of water resources systems to meet water demands and thus associating droughts with supply of and demand for water as anonomic good. Socio-economic drought occurs when the demand for an economic good exceeds supply as a result of a weather-related shortfall in water supply".

\section{The drought of 2009-2011}

Between 2009 and 2011, lower than normal rainfall was partly responsible for falling reservoir levels across the Central Karoo as the region expererienced its worst drought since 1944. Although the municipality had introduced new water tariffs as early as July 2008 to discourage high water consumption, restrictions became necessary in 
2009. These austerity measures were gradually increased as the water crisis deepened and the Gamka Dam level dropped significantly. By May 2010 the water levels of the Gamka Dam, Beaufort West's major water resource, fell faster than expected, resulting in the reservoir emptying completeley by September 2010 (See Figure 4). Consequently, 8500 households, representing approximately 36000 inhabitants, had to rely on 36 boreholes which provided 3700 kilo litre water per day. From November 2008 to December 2010, groundwater levels within the town's important North End aquifer, normally recognised for its rapid recharge capacity, dropped from 13 metre to 36 metre below ground level. On the other hand, the extremely hot and dry conditions provoked an increasing water demand.

The dire water sitaution called for emergency measures. Drastic domestic water restrictions were imposed since January 2010 and a local distaster declaration was issued for Beaufort-West. Each household was restricted to 12 kilo litre per month. At first, if consumers exceeded 15 kilo litre per day consumption, a 200\% surcharge was applied to their water accounts. In order to force down reduced water consumption, fines of R1000 were issued to perpetrators of water quotas. The water-stressed conditions prompted severe water load-shedding from September to November 2010 when both ground and surface water supplies failed. The town was divided into 12 wards staggered in 36 hour water-shedding periods to allow for the recharge of the boreholes, although the central business district, hospitals and industrial areas were not required to comply with water load-shedding. Water was supplied through static and roaming tanks and even household-level distribution of 5 litre bottled water every 48 hours. This constituted a major logistics exercise and 90 temporary municipal staff members were locally employed for the operation. In addition, a country-wide public appeal was launched via radio and newspapers to donate potable bottled water to Beaufort West $[2,19,20]$. By January 2011 visitors and private companies had dropped off 435000 litres of bottled water [21].

In January 2011 Beaufort West received relief funding amounting to R24 million from the National Treasury for South Africa's first reclamation plant. "The project was completed within six months and was the country's first direct potable reuse plant. Treated wastewater effluent is conveyed directly to a water treatment facility for further treatment to drinking water standard. Sludge from pit latrines is boiled to kill pathogens and generate water vapour, which passes through several filters for futher treatment". This further treatment include processes such as phosphate removal, pre-disinfection, ultra-filtration, reverse osmosis and advanced oxidation. The plant can process 12.3 cubic metres of sewage sludge and produce 10800 litres of drinking water per day. "The reclaimed water is pumped up to a service reservoir and blended with water from the Gamka Dam, and the 36 boreholes in six aquifers in a ratio of $1: 4^{\prime \prime}[13,22,23]$.

Nine months later, in June 2011, the Gamka Dam began to refill after substantial rainfall in its catchment associated with a cut-off low weather system. Water restrictions were also finally lifted [2].

\section{The drought of 2017-2019}


Beaufort West enjoyed a reprieve of five years before the next severe drought hit the town again, with dire consequences for its inhabitants. According to King and Karoly [24], 2017 was "set to be among the three hottest years on record" and by November 2018 Beaufort West experienced average day temperatures between 35 and $37^{\circ} \mathrm{C}$ [25]. The Gamka Dam ran dry by October 2017 already. Five more boreholes were drilled in late 2017 when the municipality received R23 million in emergency government funding. As in 2009-2011, water restrictions and water load-shedding were imposed, although the industrial areas were exempted from these measures for economic reasons. Water reduction devices such as low-pressure valves were also installed at schools. The reclamation plant, which had been the municipality's trump card since 2011 during water-stressed conditions, could normally provide $16 \%$ of the town's water needs. During the first half of 2018 it had been the last stable source of water but struggled to cope in the latter part of the year because less water became available to be cleaned and turned into potable water. The plant was designed to produce about 21.1 mega litres per day but at that rate could only produce one mega litre. On top of it all, the town's main sewage pipe broke in August 2018, which stopped waste going into the reclamation plant. This situation caused parts of the town to run out of water. By September a local distaster declaration was issued [25-29].

By 2018 and 2019, the R23 million government financial grant, e.g. to drill new boreholes and pipe water from the region south of the town, proved inadequate to meet the pressing water needs. Additional water was supplied by passing tourists and non-governmental charity organisations such as Gift of the Givers, Cape Town Water Warriors, as well as private businesses who trucked in water (See Figure 5). Eventually, the municipality distributed stocks of emergency water when each household received two 5 litre containers of water per day [25,27,30,31]. By January 2019, due to the municipality's forced distribution of emergency water, its reserve stock was critically low: there were only 700 two litre bottles of water, donated by Gift of the Givers, left in its emergency storage room [32].

Fortunately drought relief came for the inhabitants of Beaufort West when good rains returned in May 2019 and the Gamka Dam rapidly filled to $44 \%$ of its capacity. Water load-shedding was rescinded and water restrictions lowered to more tolerable levels. According to the municipality's new water distribution system each household could utilise up to 15 kilo litre water per month [33].

\section{Figures}




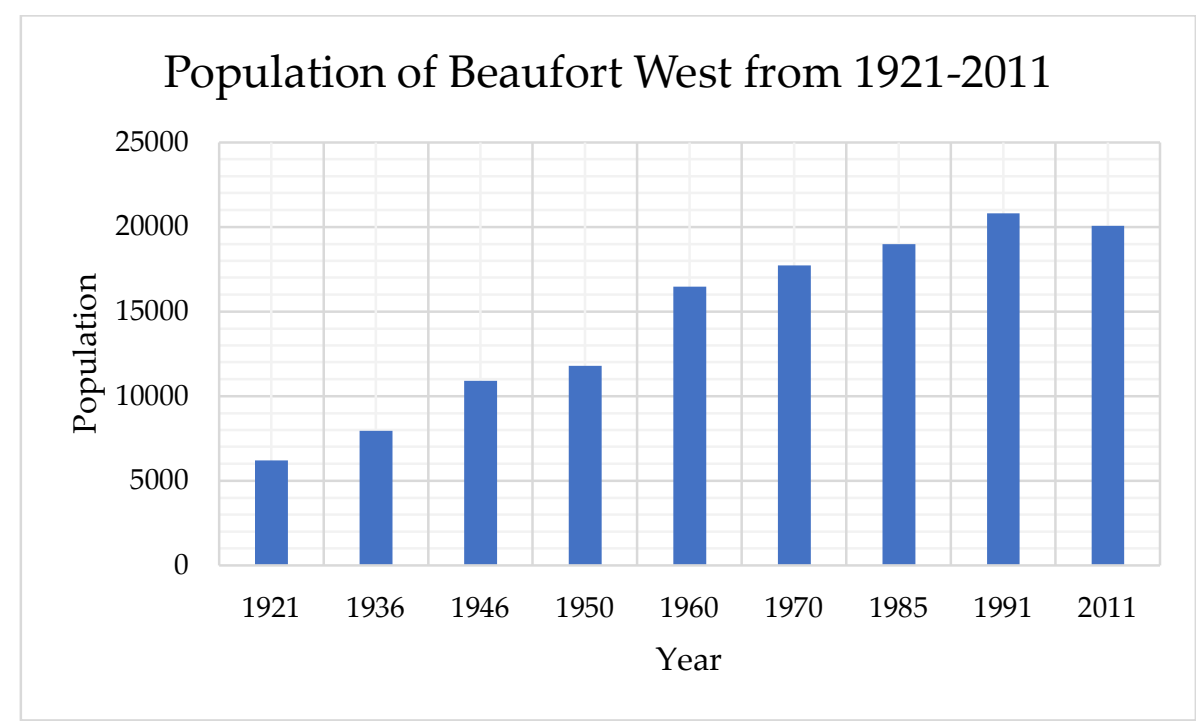

Figure 1. This is a figure. Schemes follow the same formatting.

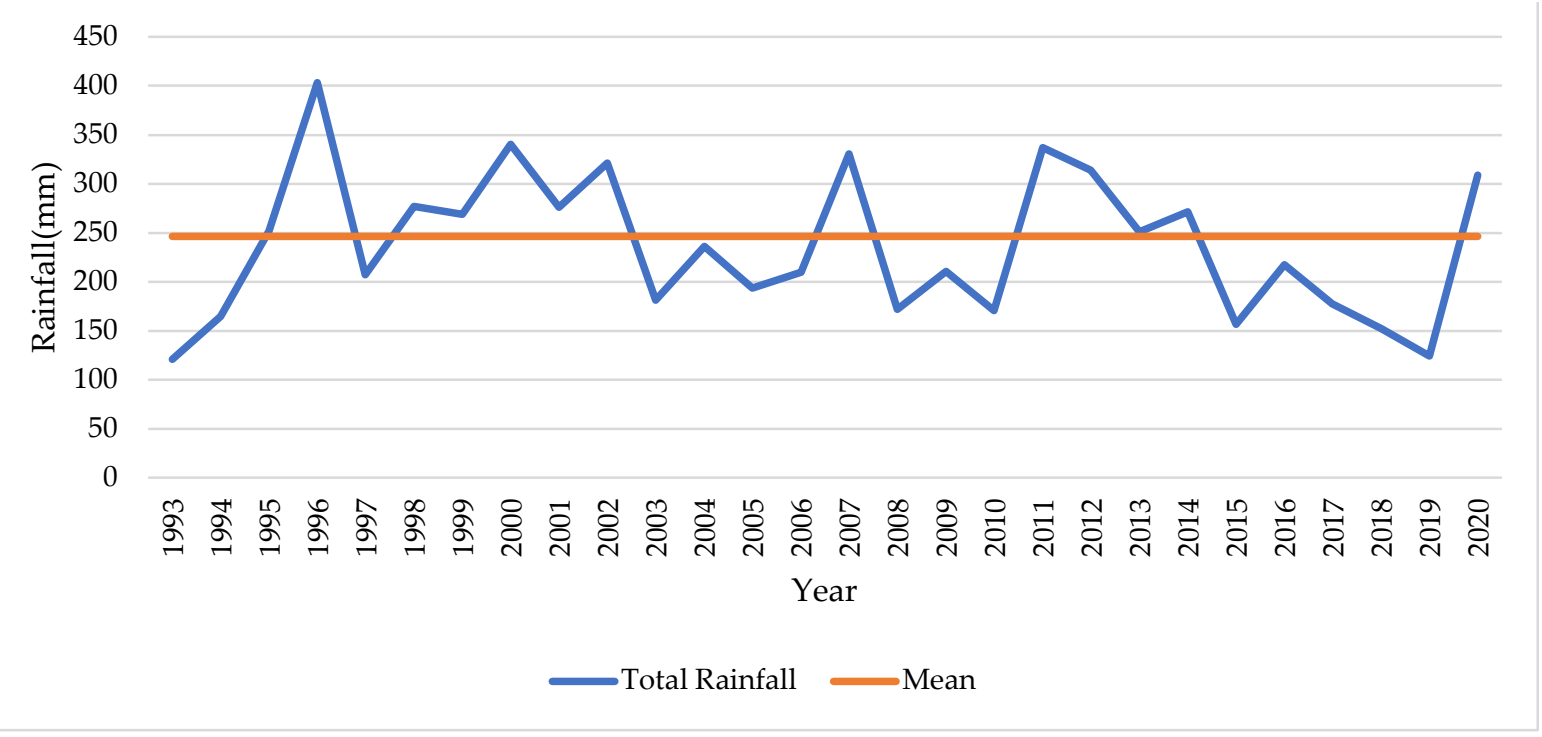

Figure 2. Beaufort West total annual rainfall 1993-2020. 


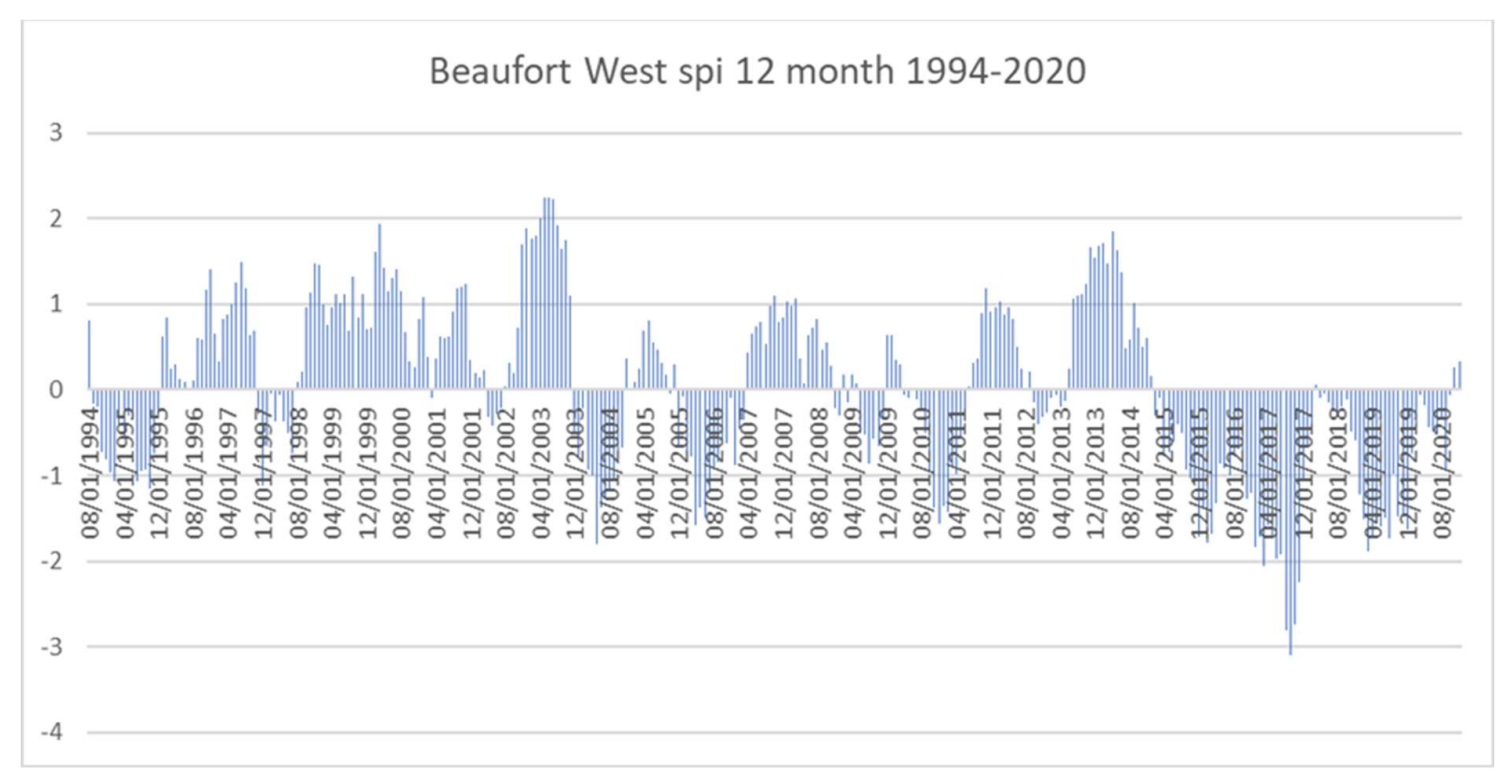

Figure 3. Beaufort West SPI 12 Month 1994-2020.

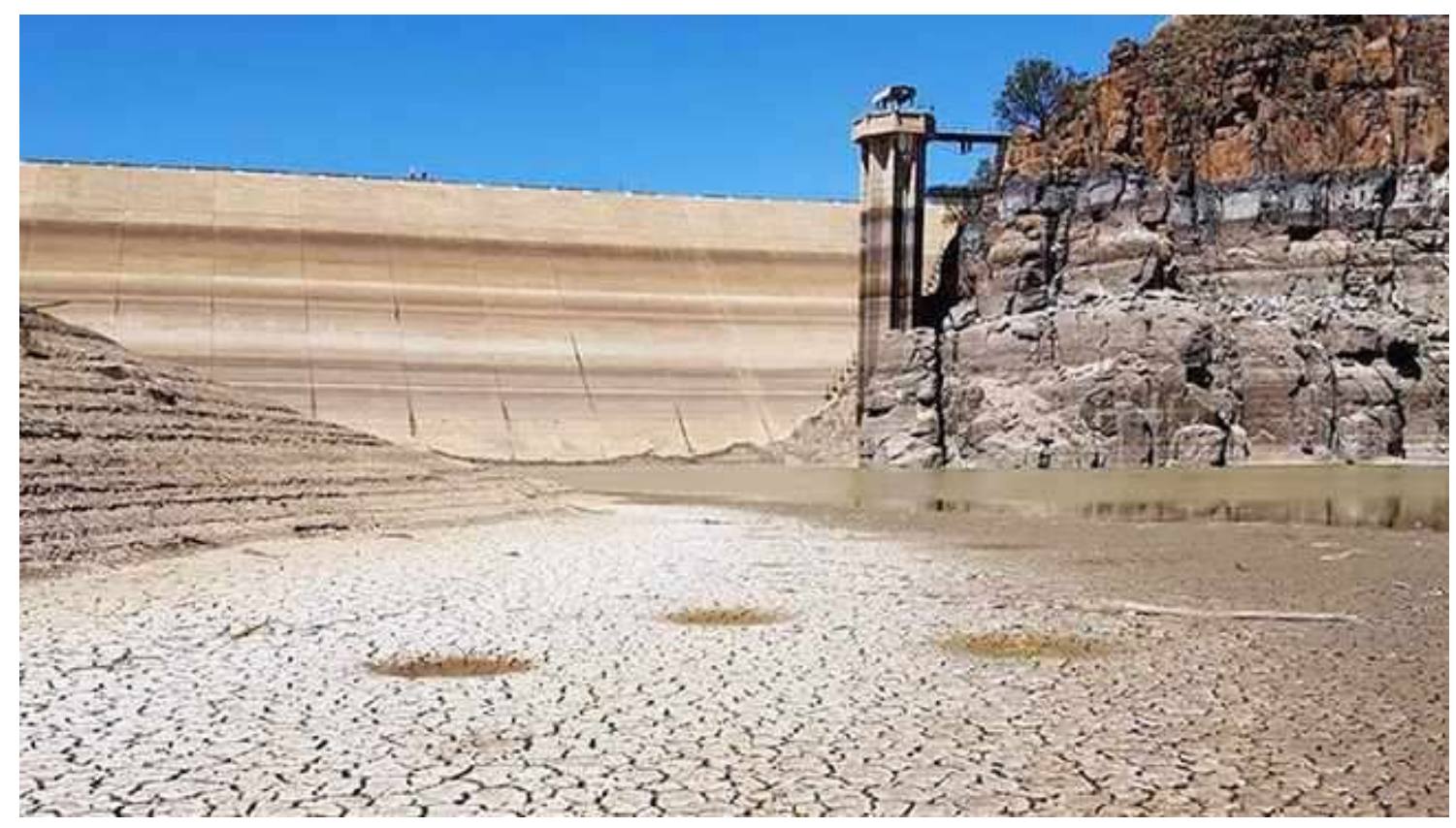

Figure 4. Gamka dam running dry 2009-2011, 2017-2019. 


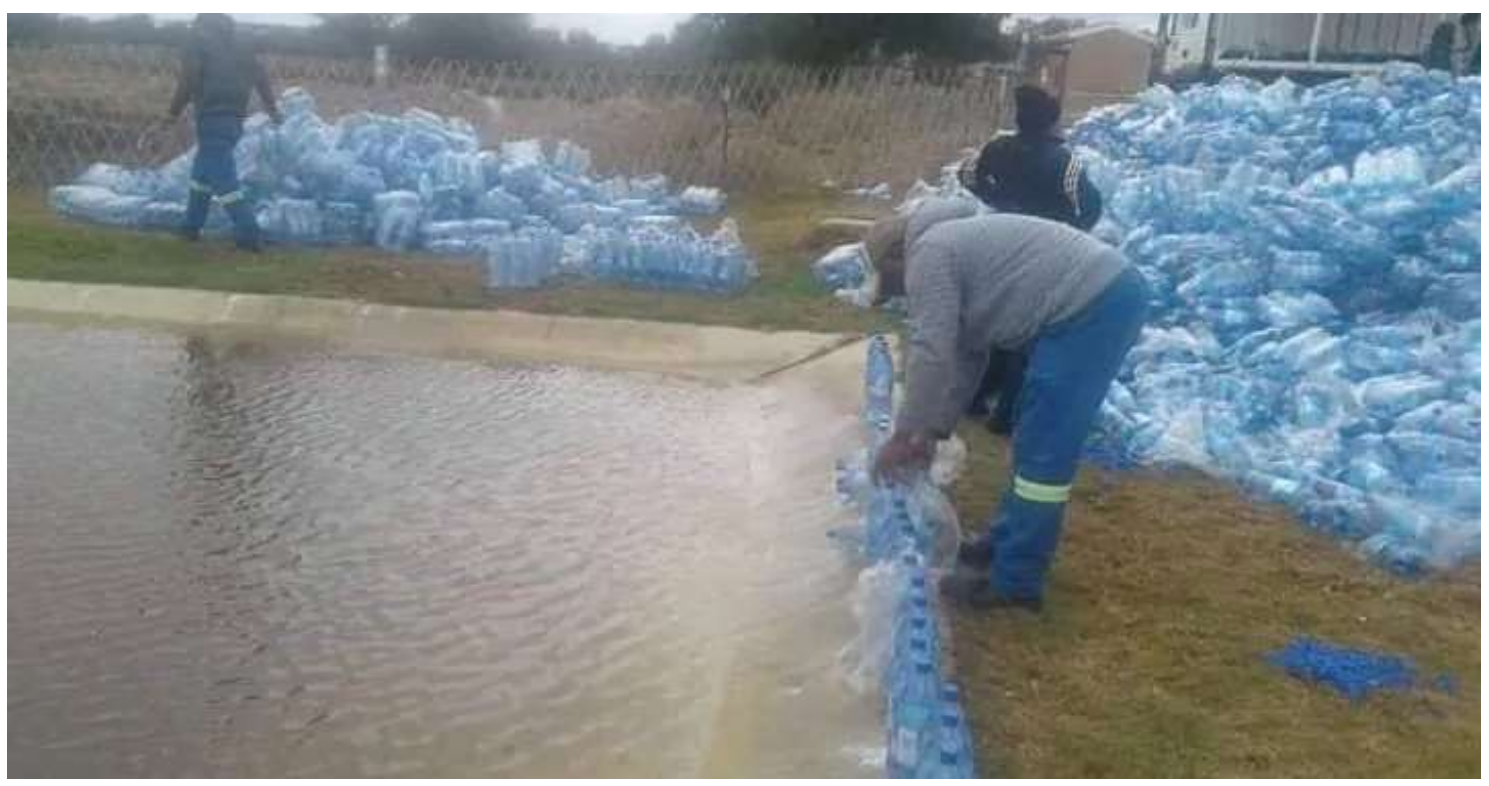

Figure 5. Municipal workers filling a retaining pond with bottled water, circa. 2019.

\section{Discussion: Lessons learnt and applied}

There are many similarities between the Beaufort West droughts of 2009-2011 and 2017-2017 and how the municipal authority dealt with severe water-stressed situations. During both drought periods austerity measures were imposed, such as water load-shedding, local disaster declarations were issued, emergency distributions of bottled water took place and external public involvement were initiated through potable water donations to Beaufort West. Although the consequences of the 2017-2019 drought have not been investigated officially as yet, the findings of the report by Holloway et al. on the Central Karoo drought of 2009-2011[2] is, in essence, applicable to both drought situations.

According to Mahed [34], "unsustainable water extraction happened in Beaufort West. On average water levels in the aquifer dropped by 25 metres over a period of twenty years due to more water being pumped out of the aquifer than recharged". A long lingering problem which preceded the droughts was that the Beaufort West municipality "faced difficulties in monitoring leaks and illegal abstractions due to outdated equipment such as water meters and infrastructure". Research by Holloway et al. [2] revealed "widespread evidence of poor or nonexistent water monitoring, with municipal water use remaining unaccounted for due to poor metering and leakages". Awareness of the town's acute water situation was, however, "increased through other measures, including the publication of names of high water users in local newspapers". A number of drought risk drivers were also identified which served as warning signs for future drought situations. There was an "increased water demand prior to the droughts that outpaced available supply, an under-recognition and investment in Integrated Water Resource Management (IWRM), including diversification of water supply options, and a limited capacity to understand and plan for concurrent drought and urban water scarcity risks. An important factor that delayed early signal detection of escalating water shortage risk was the inadequate understanding of what drought is and its interface with water scarcity. For example, in terms of IWRM anticipatory investment 
in new water infrastructure was severely limited as the Gamka Dam suffered unaccounted water losses of approximately 52\%". As the oldest municipality in South Africa Beaufort West "has an ageing and crumbling infrastructure that is prone to frequent water bursts". In addition, "population growth and town expansion were not matched by investments to address identified needs for improved water supply development. In Beaufort West a major risk driver was that the development of alternative water supplies had not kept pace with rising local demand".

In fact, the emergency demand for water involved "a tension between sustainable water resource management and basic service provision. The provision of housing and basic services to previously disadvantaged communities was identified as a key measurable municipal performance area". Therefore, factors such as "a steady growth in the provision of state housing, together with an expansion in both the number of new and the size of existing informal settlements" within the municipal boundaries of Beaufort West, all contributed to the critical water-stressed conditions during the droughts of 2009-2011 and 20172019. Overall, annual and seasonal rainfall patterns that became more and more unpredictable were identified as a major drought risk driver. "The depletion of both groundwater and supplies from the Gamka Dam resulted in the municipality drawing on water supplies from the Springfontein irrigation dam located in the town, with negative consequences for local small farmers who faced reduced supplies"'[2].

According to Meyer [21], "tourists who had been staying over in Beaufort West's guest houses had put extra pressure on the already drained resources, which in itself put severe pressure on the water supply. But the town economy needed the tourists, therefore they were accommodated". On the other hand, Holloway et al. [2] also identified some adverse socio-economic impacts of the Beaufort West droughts as the severe water restrictions and water shedding impeded the normal flow of business. Bed and breakfast businesses outside of Beaufort West's town centre "did suffer a loss of clientele" and schools were also affected by the lack of water. A local car wash was forced to close while abattoirs suffered a down-turn in production. Being a water-intense industry, it was forced to reduce the number of slaughtering days". The severe water restrictions and water shedding also impeded the normal flow of restaurants at petrol stations. In response, one of these enterprises installed two 10000 litre water tanks to keep business running during scheduled water shedding. This ensured that toilets flushed and dishes could be washed at such spots along the busy N1 auto route between Cape Town and Johannesburg. In addition, a borehole was sunk, in anticipation that the meagre water supply to the central town might dry up. "Sporting activities ceased due to a lack of available water to irrigate the school fields. In addition, an olive grove, originally planted to augment the income of one of the schools, died", because of a lack of irrigation water. Furthermore, the municipality "reported the adverse effects of reduced grey water on the functioning of the sewerage system. Poor households noted that their gardens 'died', although many attempted to maintain these with grey water". The research done by Holloway et al. "indicated that home gardens augmented livelihoods directly as a source of food or indirectly as an income source from vegetable sales. The loss of home gardening as a key drought 
amelioration strategy constituted an additional hardship for poorer households".

Matthews [22] discusses the pros and cons of Beaufort West's reclamation plant that was installed as a result of the 2009-2011 drought. According to her, "the advantages of water reclamation are that it conserves the available water supply, which reduces the need to abstract more water from surface or groundwater sources, or build new dams, all of which have environmental and financial costs. It also reduces the volume of treated effluent discharged back into aquatic systems, where it may degrade natural water quality and cause the ripple-effect of ecological changes associated with nutrient enrichment. On the other hand, water reclamation for drinking purposes is considerably more expensive. Potable reuse plants employing reverse osmosis as a treatment method have high energy costs, because the process relies on highpressure pumping to overcome osmotic pressure. The Beaufort West reclamation plant uses the reverse osmoses process as part of a multiplebarrier approach that also incorporates, as said, rapid sand filtration, ultra-filtration, UV-hydrogen peroxide and final chlorination. Reverse osmosis also pushes up costs because of highly concentrated brine, produced as a by-product, which is difficult to dispose of. Fortunately, the Beaufort West plant has some extra evaporation ponds available at the wastewater treatment works and the volumes are reasonably low".

\section{Conclusions}

In terms of its drought experiences in 2009-2011 and 2017-2019 Beaufort West faced the same problems that many of South Africa's other inland towns face in the new millennium [27]. Holloway, et al. [2] ascertained that "the severity of these droughts in the Central Karoo was amplified by interacting risk drivers that had progressively escalated the risk of a wide-spread water shortage. These included greatly increased water consumption prior to the onset of meteorological drought conditions, both in agriculture and in a rapidly growing town population. Prior to the drought emergency such conditions had been accompanied neither by rigorous water demand management, nor systematic investment in water infrastructure and the requisite technical capacity to manage water supplies sustainably. Water resource development had not kept pace with demand. These risks were further exacerbated by a lack of systematic drought risk management planning".

Muller [35] states that "South Africa's rainfall has always been variable and unpredictable" and claims that "reliable supplies can be provided to urban water users if storage infrastructure is built with enough capacity to cope with regular dry periods, but such infrastructure has to be managed with a watchful eye on the ever-changing climate. If water is withdrawn without restraint during a dry period, shortages will be the likely outcome". Muller [36] also argues that "drought research should no longer view water availability as a solely natural, climateimposed phenomenon and water use as a purely socio-economic phenomenon, and instead more carefully consider the multiple interactions between both". In similar vein, after the 2017-2019 drought, H. Haarhoff, Beaufort West's municipal manager, pleaded with the community that a water-saving culture should be maintained while remaining hopeful that a normal rainfall pattern would return [33].

It is quite clear that equilibrium should be reached between the water expectations of the community and the water availability in water- 
stressed towns such as Beaufort-West. Klopper [37] observed that in many Karoo towns local authorities will have to face a growing hostility among inhabitants should water supply become frequently unavailable. With ageing infrastructure, prolonged droughts and increasing population growth many of these towns do not enjoy a seamless, uninterrupted water supply anymore - a sure instigator of future social instability in such communities.

Author Contributions: Not applicable.

Funding: This research received no external funding.

Data Availability Statement: Data utilized in this study is available at Statistics South Africa http://www.statssa.gov.za/?page $\mathrm{id}=4286 \& \mathrm{id}=286$ and on the rainfall data website of the Department of Water and Sanitation, https://www.dws.gov.za/Hydrology/Unverified/DetailRainfall.aspx?Station=J2R $\underline{004 F W \& T y p e=F l o w \& R a i n=Y}$

Acknowledgments: The author acknowledges the support and assistance of Rouxan Rademan, student research assistant, in the gathering of census and rainfall data, respectively.

Conflicts of Interest: The author declares no conflict of interest.

\section{References}

1. Le Maitre, D.; Colvin, C.; Maherry, A. Water Resources in the Klein Karoo: The Challenge of Sustainable Development in a Water-Scarce Area. South African Journal of Science 2009, 105, 39-48, doi:10.1590/S003823532009000100019.

2. Holloway, A.; Fortune, G.; Zweig, P.; Barrett, L.; Benjamin, A.; Chasi, V.; de Waal, J. Eden E Central Karoo Drought Disaster 2009 - 2011: The Scramble for Water; Stellenbosch University: Stellenbosch, 2012; pp. 1-119, Available online:

http://www.riskreductionafrica.org/assets/files/EDEN\%20and\%20CENTRAL\%20KAROO\%20DROUGH T\%20DISASTER\%202009.pdf (accessed on 8 April 2021).

3. Meissner, R.; Jacobs-Mata, I. South Africa's Drought Preparedness in the Water Sector: Too Little too Late? South African Institute of International Affairs Policy Briefing 2016, 155, 1-4, https://saiia.org.za/research/south-africas-drought-preparedness-in-the-water-sector-too-little-too-late/.

4. Schreiner, B.G.; Mungatana, E.D.; Baleta, H. Impacts of Drought Induced Water Shortages in South Africa: Economic Analysis; WRC Report No. 2604/1/18; Water Research Commission: Gezina, South Africa, 2018; pp. 1-85, Available online: http://www.wrc.org.za/wp-content/uploads/mdocs/2604\%20Vol\%201.pdf (accessed on 22 June 2021).

5. Tfwala, C.M.; van Rensburg, L.D.; Schall, R.; Dlamini, P. Drought Dynamics and Interannual Rainfall Variability on the Ghaap Plateau, South Africa, 1918-2014. Physics and Chemistry of the Earth, Parts A/B/C 2018, 107, 1-7, doi:https://doi.org/10.1016/j.pce.2018.09.003.

6. Zhang, H.; Xu, Y.; Kanyerere, T. A Modelling Approach to Improving Water Security in a DroughtProne Area, West Coast, South Africa. Physics and Chemistry of the Earth, Parts A/B/C 2019, 114, 102797, doi:https://doi.org/10.1016/j.pce.2019.08.005.

7. Visser, W.P. A Perfect Storm: The Ramifications of Cape Town's Drought Crisis. The Journal for Transdisciplinary Research in Southern Africa 2018, 14, 1-10, doi:doi:10.4102/td.v14i1.567.

8. Statistics South Africa. Beaufort West. Available online: http://www.statssa.gov.za/?page_id=4286\&id=286 (accessed on 2 May 2021).

9. Mishra, A.K.; Singh, V.P. A Review of Drought Concepts. Journal of Hydrology 2010, 391, 202-216, doi:https://doi.org/10.1016/j.jhydrol.2010.07.012.

10. DWS Rainfall Data. Available online: https://www.dws.gov.za/Hydrology/Unverified/DetailRainfall.aspx?Station=J2R004FW\&Type=Flow\&R ain $=Y$ (accessed on 10 December 2021).

11. Vivier, W.G.H.; Vivier, S. Hooyvlakte: Die Verhaal van Beaufort-Wes 1818-1968; Nasionale Boekhandel: Cape Town, South Africa, 1970. 
12. Erasmus, G.J. Navorsingsverslag: Sub-streek: Die Sentrale Karoo: Gebied: Beaufort-Wes en Omgewing; Stellenbosch University: Stellenbosch, South Africa, 1986.

13. Marais, P.; Von Durckheim, F. Beaufort West Water Reclamation Plant: Project. Water E Sanitation Africa 2012, 7, 20-25, doi:10.10520/EJC106532.

14. Xu, Y.; Mahed, G.; Van Wyk, Y.; Lin, L.; Sun, X.; Xiao, L.; Talma, S. Towards a Sampling and Monitoring Protocol of Radioactive Elements in Fractured Rock Aquifers for Groundwater Re-source Security in Beaufort West: Report to the Water Research Commission; WRC Report No. 1694/1/12; Water Research Commission: Gezina, South Africa, 2012, Available online: https://www.researchgate.net/publication/272495076 (accessed on 27 November 2020).

15. Visser, W.P. Between Drought and Deluge: A History of Water Provision to Beaufort West, ca. 18581955. New Contree 2020, 85, 1-21, http://hdl.handle.net/10394/36923.

16. WCARS, 3/BFW, Vol. 1/1/1/23, Minutes of a Special Council Meeting, 1946, pp. 401-402 and Minutes of a Special Council Meeting, 1949, pp. 970-971; Western Cape Archives and Records Service: Cape Town, South Africa.

17. WCARS, 3/BFW Box 263, Vol. 5/1/14, Louw, C.A.; Munisipaliteit Beaufort-Wes Rioolskema Vorderingsverslag, 1977; Western Cape Archives and Records Service: Cape Town, South Africa.

18. Nel, E.; Taylor, B.; Hill, T.; Atkinson, D. Demographic and Economic Changes in Small Towns in South Africa's Karoo: Looking from the Inside Out. Urban Forum 2011, 22, 395, doi:10.1007/s12132-011-9131-z.

19. Burger, K. Gee jou Water vir Beaufort. Rapport, 12 December 2010, 5. Available online: https://www.news24.com/news24/nuus24/suid-afrika/nuus/gee-jou-water-vir-beaufort-20101212 (accessed on 20 June 2021).

20. Steyn, T. Beaufort-Wes het weer genoeg water. Die Burger, 16 February 2011, 6. Available online: https://www.news24.com/news24/nuus24/suid-afrika/nuus/gee-jou-water-vir-beaufort-20101212 (accessed on 20 June 2021).

21. Meyer, W. Water from sewage for Karoo town. Weekend Argus, 1 January 2011. Available online: https://www.iol.co.za/news/south-africa/weste rn-cape/water-from-sewage-for-karoo-town-1006911 (accessed on 3 May 2021).

22. Matthews, S. Water - Precious Resource to be used Again, and Again and Again... Water Wheel 2015, 14, 26-29, http://www.wrc.org.za/wp-content/uploads/mdocs/WaterWheel_2015_3_May.pdf.

23. Sorensen, P. The Chronic Water Shortage in Cape Town and Survival Strategies. International Journal of Environmental Studies 2017, 74, 515-527, doi:10.1080/00207233.2017.1335019.

24. King, A.; Karoly, D. 2017 is set to be Among the Three Hottest Years on Record. The Conversation, 6 November 2017. Available online: https://theconversation.com/2017-is-set-to-be-among-the-threehottest-years-on-record-86934 (accessed on 17 May 2021).

25. Lepule, T. Beaufort West Needs Water after Long Drought. IOL, 4 November 2018. Available online: https://www.iol.co.za/weekend-argus/beaufort-west-needs-water-after-long-drought-17765948 (accessed on 14 April 2021).

26. Sonnekus, S. Beaufort-Wes nog nie hééltemal droog. Die Burger, 14 November 2017, 10.

27. Kings, S.; Ritchie, G. Beaufort West Runs out of Water. Mail \& Guardian, 24 August 2018. Available online: https://mg.co.za/article/2018-08-24-00-beaufort-west-runs-out-of-water/ (accessed on 14 April 2021).

28. Kruger, J. Beurtwater ingestel op Beaufort-Wes. Die Burger, 6 September 2018, 6.

29. Nienaber, M. Wes-Kaap Help dié Dorpe, Hospitale, Skole eerste met Boorgate. Die Burger, 25 November 2017, 11.

30. Kruger, J. Dag Zero kán voorkom word. Die Burger, 30 December 2017, 7.

31. Kruger, J. Beurtwater maak nog verskil in dorp. Die Burger, 7 September 2018, 7.

32. Somdyala, K. Beaufort West about to Run out of Emergency Bottled Water - Official. News24, 23 January 2019. Available online: https://www.news24.com/SouthAfrica/News/beaufort-west-about-torun-out-of-emergency-bottled-water-official-20190123 (accessed on 1 May 2021).

33. Kruger, J. Beurtwater in Beaufort-Wes opgehef en perke aangepas. Die Burger, 15 May 2019, 1.

34. Mahed, G. Explainer: What there is to Know about South Africa's Aquifers. The Conversation, 5 September 2018, 1-3. Available online: https://theconversation.com/explainer-what-there-is-to-knowabout-south-africas-aquifers-102660 (accessed on 20 June 2021).

35. Muller, M. South Africa's Real Water Crisis: Not Understanding What's Needed. The Conversation, 6 November 2019. Available online: https://theconversation.com/south-africas-real-water-crisis-notunderstanding-whats-needed-126361 (accessed on 5 March 2021). 
36. Muller, M. Not all Droughts are the Same: Here's what's Different about Them. The Conversation, 19 November 2019. Available online: https://theconversation.com/not-all-droughts-are-the-same-hereswhats-different-about-them-127238 (accessed on 16 April 2021).

37. Klopper, H. The Organised Expansion and Permanent Settlement of People in Boesmanland in Correlation with Accessible Water Sources, 1760-c.1960. Stellenbosch University, Stellenbosch, South Africa, 2020. Available online: http://hdl.handle.net/10019.1/108154 